\title{
THE AMELIORATING EFFECT OF UNCOOKED BEANS DIET IN CD-1 MICE
}

\author{
ADUEMA W ${ }^{1 *}$, AGBAI JU ${ }^{2}$, WARISO AC ${ }^{3}$ \\ ${ }^{1}$ Department of Medical Physiology, Gregory University, Uturu, Abia State, Nigeria. ${ }^{2}$ Department of Human Anatomy, Abia State University, \\ Uturu, Abia State, Nigeria. ${ }^{3}$ Department of Human Physiology, Abia State University, Uturu, Abia State, Nigeria. \\ Email: Wadioniaduema@gmail.com
}

Received: 09 January 2019, Revised and Accepted: 22 Feb 2019

\section{ABSTRACT}

This study was, therefore, designed to investigate the ameliorating effect of uncooked beans on pain sensation using three groups of Swiss white mice (control and test) weighing $20 \mathrm{~g}-30 \mathrm{~g}(\mathrm{n}=10 \mathrm{each})$. The control group received normal rodent chow, while the test group received $15 \mathrm{~g}$ of uncooked beans in $15 \mathrm{~g}$ of rodent chow per day and serotonin precursor 5-hydroxytryptophan $(0.2 \mathrm{mg} / 15 \mathrm{~g} \mathrm{w} / \mathrm{w})$ diet. Water was given ad libitum while daily food and water intake, as well as body weight changes, were monitored during the 30-day study. The formalin tests were used to assess pain sensation. The results showed that in the formalin test, the frequencies and durations of paw licks and paw attention in both phases of the test were significantly lower $(\mathrm{p}<0.05)$ compared to the control group. Therefore, consumption of uncooked Nigerian beans diet decreases pain sensation in mice.

Keywords: Beans, Pain, Formalin and mice.

(C) 2020 The Authors. Published by Innovare Academic Sciences Pvt Ltd. This is an open access article under the CC BY license (http:/ / creativecommons.org/ licenses/ by/ 4.0/ ) DOI: http:/ / dx.doi.org/ 10.22159/ ijms.2019.v7i1.24184

\section{INTRODUCTION}

Legumes, also called pulses, are another name for beans, peas, and lentils in the United Kingdom. Beans, such as the iron beans in Nigeria, are considered as good source of protein, iron, zinc, calcium, dietary fibers, and some minerals and vitamins that may prevent cancer and heart disease [2,7]. In addition to these nutritional components, Nigerian beans are rich in a variety of several phytochemicals with potential health benefits such as flavonoids, alkaloids, saponins, glycosides, and tannin, among others [3,6]. Beans are also said to contain serotonin and its precursor 5-hydroxytryptophan (5-HTP) [11]. Since beans contain chemicals that can potentially affect neurobehavioral patterns, it is, therefore, pertinent to find out whether the chronic consumption of uncooked Nigerian beans diet can ameliorate pain sensation.

\section{MATERIALS AND METHODS}

\section{Experimental animals/grouping}

A total of 30 adult male Swiss white mice weighing between 20 and $30 \mathrm{~g}$ were bought and kept at the animal house of the Department of Human Physiology, Abia State University. The animals were acclimatized under standard laboratory conditions and given free access to normal feed and clean drinking tap water. The animals were randomly assigned into three groups, control and a test group. The animals in the control group received normal feed only, while the test groups received mixed feed of $15 \mathrm{~g}$ powdered uncooked beans per every $15 \mathrm{~g}$ of rodent chow and $(0.2 \mathrm{mg} / 15 \mathrm{~g})$ serotonin precursor diet for 30 days.

\section{Experimental design}

The formalin test was used to test for pain sensation as developed by Abbott et al., 1981 [1]. Each mouse was picked by the base of its tail and $0.2 \mathrm{ml}$ of $2.5 \%$ formalin was injected into the right hind paw of the mouse using a needle and syringe. The animal was placed in the observation box and observed for $5 \mathrm{~min}$. The animal was then returned to its cages and allowed for $30 \mathrm{~min}$ before it was taken back to the observation box to be reobserved for another $5 \mathrm{~min}$. This procedure was repeated for each animal.

Behavior scored during the pain test included the following:

- Frequency of the right hind lick/scratch

- Frequency of the right hind paw attention

- Duration of paw lick and paw attention.

\section{Statistical analysis}

Data obtained from the experiments were statistically analyzed using Microsoft Excel, with factorial ANOVA/t-test in the statistics program start view version for Windows or Mac. Post hoc comparison was also done using the Student \pm Newman-Keuls design. Values were represented as mean \pm standard error of the mean and "p" $<0.05$ and $\mathrm{p}<0.001$ were considered as statistically significant.

\section{RESULTS}

Fig. 1 shows the frequency of the right hind paw licks for mice fed normal, uncooked beans, and serotonin precursor diets as $14.90 \pm 1.59$, $7.71 \pm 0.75$, and $5.71 \pm 0.42 / 5 \mathrm{~min}$, respectively, in the first trial after 5 min of formalin administration denoting acute pain. The frequency of paw lick for the mice fed uncooked beans and serotonin precursor diet was significantly shorter $(p<0.05)$ than that of the control fed mice. In the second trial after $30 \mathrm{~min}$ of formalin administration denoting chronic pain, the frequency of paw licks was $0.87 \pm 0.22$, $0.14 \pm 0.14$, and $0.14 \pm 0.14 / 5$ min for mice fed normal, uncooked beans, and serotonin precursor diet, respectively. The frequency of the right hind paw lick in the uncooked beans and serotonin precursor diet-fed mice was significantly shorter $(p<0.05)$ than those of the control fed mice.

The values for the duration of hind paw lick following administration of normal, uncooked beans, and serotonin precursor diets were $26.79 \pm 2.56,17.75 \pm 2.32$, and $8.67 \pm 2.08$ seconds, respectively, in the first $5 \mathrm{~min}$. The duration of hind paw lick in the uncooked beans and serotonin precursor fed mice was significantly lower $(\mathrm{p}<0.05)$ compared to control. In the second trial, after $30 \mathrm{~min}$ of formalin administration, the hind paw lick duration in the group of mice fed normal, uncooked beans, and serotonin precursor diets was $1.30 \pm 0.52,0.16 \pm 0.16$, and $0.16 \pm 0.16 \mathrm{~s}$, respectively. The duration of hind paw lick was significantly lower in the uncooked bean and serotonin precursor fed mice compared to the control group (p<0.05), Fig. 2 .

The values for the frequency of hind paw attention following administration of normal, uncooked beans, and serotonin precursor diet were $24.00 \pm 2.07,8.14 \pm 1.18$, and $6.00 \pm 0.82 / 5 \mathrm{~min}$, respectively, in the first trial after $5 \mathrm{~min}$ of formalin administration. The frequency of hind paw attention was significantly lower in the uncooked beans and serotonin precursor fed mice compared to control $(\mathrm{p}<0.05)$. In 
the second trial, after 30 min of formalin administration, the values were $1.20 \pm 0.47,0.43 \pm 0.30$, and $0.43 \pm 0.30$. The frequency of hind paw attention was significantly lower in the serotonin precursor and uncooked beans group compared to control ( $p<0.05$ ), Fig. 3 .

The values for the duration of hind paw attention following administration of normal, uncooked beans, and serotonin precursor diet were $89.38 \pm 11.33,53.59 \pm 4.14$, and $39.03 \pm 5.51 \mathrm{~s}$, respectively The duration of hind paw attention fed with uncooked beans and serotonin precursor was statistically shorter than those fed with control diet $(\mathrm{p}<0.05)$. In the second trial, after $30 \mathrm{~min}$ of administration of formalin, the duration of paw attention was $2.60 \pm 0.60,0.37 \pm 0.24$, and $0.55 \pm 0.39 \mathrm{~s}$, respectively. The duration of hind paw attention was significantly lower in the uncooked beans and serotonin precursor fed mice compared to control ( $\mathrm{p}<0.05)$, Fig. 4.

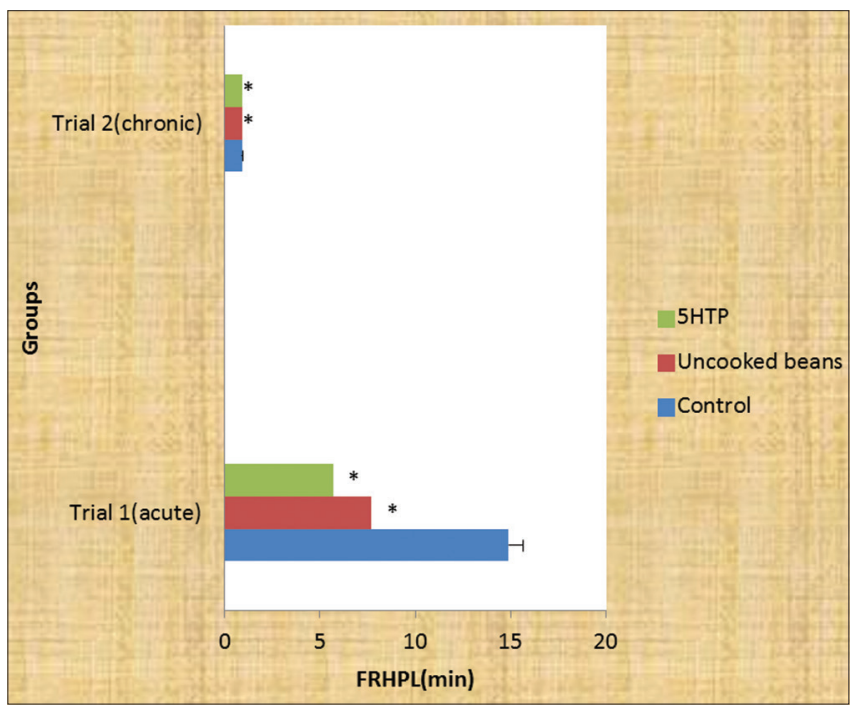

Fig. 1: Right hind paw lick frequency of the different experimental groups after two trials during the assessment of pain using formalin. Values are expressed as mean \pm standard error of the mean, $\mathrm{n}=10,{ }^{*} \mathbf{p}<\mathbf{0 . 0 5}$ versus control

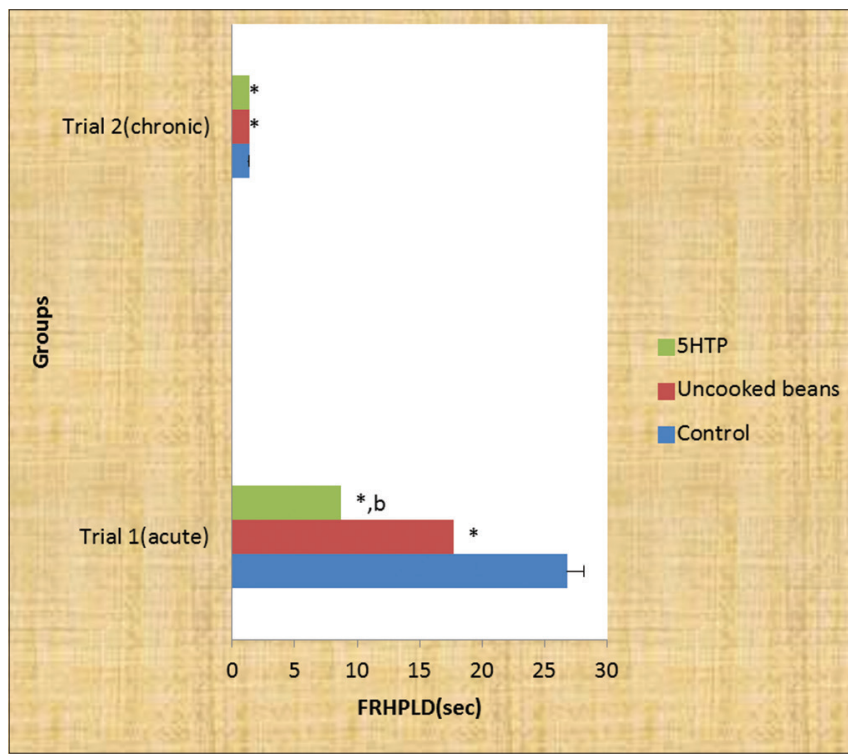

Fig. 2: Right hind paw lick duration of the different experimental groups after two trials during the formalin test assessment for pains. Values are expressed as mean \pm standard error of the mean, $\mathrm{n}=10,{ }^{*} \mathrm{p}<\mathbf{0 . 0 5}$ versus control; $\mathrm{b}=\mathrm{p}<\mathbf{0 . 0 5}$ versus uncooked beans

\section{DISCUSSION}

The formalin test was in two phases. The response within the first $30 \mathrm{~s}$ following formalin injection is the perception of acute pain, while the later period shows chronic pain perception. Frequency of hind paw attention and hind paw licking following formalin injection was defined as the number of times the mice lick or shake their hind paw after injection with formalin. Lower frequencies of hind paw attention and hind paw licking indicate analgesic effect while higher frequencies indicate hyperalgesia. Our finding showed that during acute and chronic phases of pain, the beans diet-fed mice and that of the serotonin precursor fed mice had significantly less pain perception compared to control since the frequencies and durations of hind paw lick and hind paw attention following formalin injection

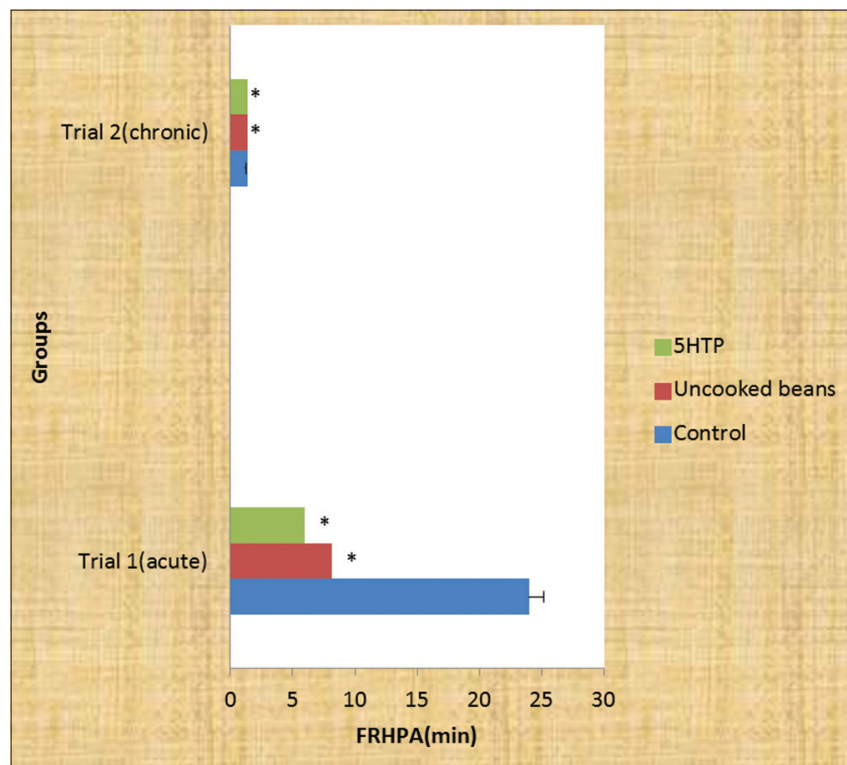

Fig. 3: Frequency of right hind paw attention of the different experimental groups after two trials during the formalin test assessment for pains. Values are expressed as mean \pm standard error of the mean, $n=10, * p<0.05$ versus control

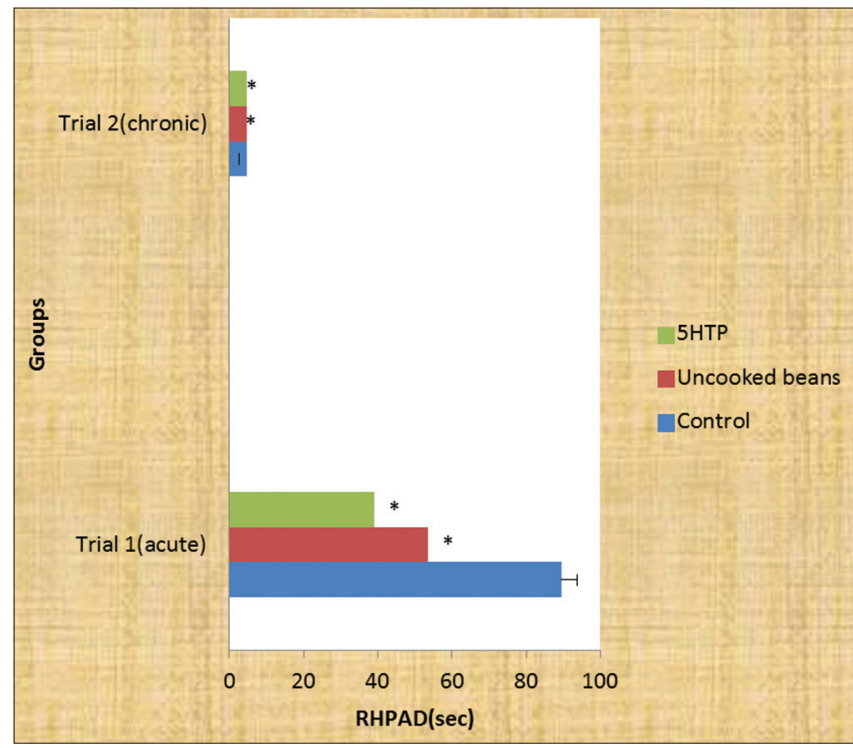

Fig. 4: Right hind paw attention duration of the different experimental groups after two trials during the formalin test assessment for pains. Values are expressed as mean \pm standard error of the mean, $\mathbf{n}=10,{ }^{*} \mathbf{p}<0.05$ versus control 
were significantly lower in the beans and serotonin precursor diet-fed mice than the control. Pain reduction was observed on the first and second phases of pain following chronic consumption of beans diet. It is, therefore, interesting to note that beans diet can be beneficial in the reduction of chronic pain if the results in mice can be extrapolated to man. Our findings suggest that uncooked beans and serotonin precursor diet mice showed less sensitive to pain when compared to those fed with the control diet. Beans diet may have decrease pain sensitivity due to the presence of flavonoids and phlobatannins in the beans which has been reported to reduce pain perception due to their anti-inflammatory properties $[4,8]$. Similarly, this may also be so because beans contain 5-HTP (serotonin precursor) and 5-HT (serotonin) that play a positive role in the brain analgesia system.

\section{CONCLUSION}

It is, therefore, interesting to note that uncooked Nigerian beans diet commonly called iron beans may be beneficial in the reduction of chronic pain if our results can be extrapolated to humans.

\section{ACKNOWLEDGMENT}

We acknowledged Mr. and Mrs. B.A. Aduema, Dr. Iwasam Joshua, and Associate Prof. A.A. Nwankwo for their support.

\section{AUTHOR(S) CONTRIBUTIONS}

All authors have contributed one way or the other to the success of this paper and there is no conflict in relation to funding or whatsoever that may prevent the publication of this piece.

\section{REFERENCES}

1. AbbottFV, Franklin KB, Ludwick RJ, Melzack R. Apparent lack of tolerance in the formalin test suggests a different mechanism for morphine analgesia in different types of pain. Pharmacol Biochem Behav 1981;15:637-40.

2. Adeyele EJ. Studies of Chemical Composition and Functional Properties of African Yambeans (Spensotylis stenoorpa) flour. Ph, D Thesis. Nigeria: Department of Chemistry, Federal University of Technology, Akure, Ondo State; 1995.

3. Dorria E, Campion B, Sparvoli F, Tava A, Nielsin E. Antinutient components and metabolites with health implications in seeds of 10 bean (Phaseolus vulgaris and Phaseolus linutus) landraces cultivated on Southern Ltaly. J Food Compos Anal 2012;26:72-80.

4. Hong XI, Song FL. Activity of plant flavenoids against antibiotic resident bacteria. Phythother Res 2001;15:39-43.

5. Ito S, Okuda-Ashiteka E, Minami T. Central and peripheral roles of prostaglandins in pain and their interactions with novel neuropathies Nociceptin and nocistatin. Neurosci Res 2001;41:299-332.

6. Lyimo M, Mugula J, Elias T. Nutritive composition of broth from selected bean varieties cooked for various periods. J Sci Food Agric 1992;58:535-9.

7. John FM. The Encyclopedia of American Food and Drink. New York: Lebhar-Friendman Books; 1999. p. 380.

8. Muller H. Hindu Medicine. Baltimore: The John Hopkins Press; 1992.

9. Osim EE. Neurophysiology. Calabar: University of Calabar Press; 2008. p. 24-7.

10. Osim EE. Our Consumables and Our Emotions. Calaber: Faculty of Basic Medical Science, University of Calaber, Lecture Series; 2012.

11. Portas CM, Bjorvatn B, Ursin R. Serotonin and the sleep/wake cycle: Special emphasis on microdialysis studies. Prog Neurobiol 2000;60:13-35.

12. Roefof P, Perkins KA. Relationship between pain and fear. Am J Public Health 2004;70:420.

13. Sembulingam K, Sembulingam P. Neurophysiology of pain. In: Essentials of Physiology. New Delhi: Jaypee Brothers, Medical Publishers; 2010. p. 803-10. 